\title{
Chitosan-Based Nanocomposites for Glyphosate Detection Using Surface Plasmon Resonance Sensor
}

\author{
Minh Huy Do ${ }^{1,2}$, Brigitte Dubreuil ${ }^{1}$, Jérôme Peydecastaing ${ }^{1}$, Guadalupe Vaca-Medina ${ }^{1,3}$, \\ Tran-Thi Nhu-Trang ${ }^{4}$, Nicole Jaffrezic-Renault ${ }^{5}$ and Philippe Behra ${ }^{1,2, *}$ \\ 1 Laboratoire de Chimie Agro-industrielle, LCA, Université de Toulouse, INRAE, \\ 31030 Toulouse CEDEX 4, France; huyminh.do@ensiacet.fr (M.H.D.); brigitte.dubreuil@ensiacet.fr (B.D.); \\ jerome.peydecastaing@ensiacet.fr (J.P.); guadalupe.vacamedina@ensiacet.fr (G.V.-M.) \\ 2 "Water-Environment-Oceanography" Department, University of Science and Technology of Hanoi (USTH), \\ Vietnam Academy of Science and Technology (VAST), 100000 Hanoi, Vietnam \\ 3 Centre d'Application et de Traitement des Agroressources (CATAR), Université de Toulouse, \\ 31030 Toulouse CEDEX 4, France \\ 4 Faculty of Environmental and Food Engineering, Nguyen Tat Thanh University (NTTU), \\ 700000 Ho Chi Minh, Vietnam; ttntrang@ntt.edu.vn \\ 5 Institute of Analytical Sciences, UMR 5280 CNRS-Université Claude Bernard, 69100 Villeurbanne, France; \\ nicole.jaffrezic@isa-lyon.fr \\ * Correspondence: philippe.behra@ensiacet.fr
}

Received: 7 July 2020; Accepted: 14 October 2020; Published: 21 October 2020

\begin{abstract}
This article describes an optical method based on the association of surface plasmon resonance (SPR) with chitosan (CS) film and its nanocomposites, including zinc oxide (ZnO) or graphene oxide (GO) for glyphosate detection. $\mathrm{CS}$ and $\mathrm{CS} / \mathrm{ZnO}$ or $\mathrm{CS} / \mathrm{GO}$ thin films were deposited on an Au chip using the spin coating technique. The characterization, morphology, and composition of these films were performed by Fourier-transform infrared spectroscopy (FTIR), atomic force microscopy (AFM), and contact angle technique. Sensor preparation conditions including the cross-linking and mobile phase ( $\mathrm{pH}$ and salinity) were investigated and thoroughly optimized. Results showed that the $\mathrm{CS} / \mathrm{ZnO}$ thin-film composite provides the highest sensitivity for glyphosate sensing with a low detection limit of $8 \mathrm{nM}$ and with high reproducibility. From the Langmuir-type adsorption model and the effect of ionic strength, the adsorption mechanisms of glyphosate could be controlled by electrostatic and steric interaction with possible formation of 1:1 outer-sphere surface complexes. The selectivity of the optical method was investigated with respect to the sorption of glyphosate metabolite (aminomethylphosphonic acid) (AMPA), glufosinate, and one of the glufonisate metabolites (3-methyl-phosphinico-propionic acid) (MPPA). Results showed that the SPR sensor offers a very good selectivity for glyphosate, but the competition of other molecules could still occur in aqueous systems.
\end{abstract}

Keywords: pesticides; glyphosate; surface plasmon resonance; chitosan; nanocomposites; ZnO; graphene oxide

\section{Introduction}

Glyphosate (N-(phosphonomethyl)glycine), the world most widely applied herbicide in agriculture and urban areas [1], was first synthesized by the Swiss chemist Henri Martin in 1950 [2] as a potential pharmaceutical compound [3]. A phosphonomethyl derivative of the amino acid glycine (Figure 1) [4], glyphosate is very polar, highly soluble in water $\left(12 \mathrm{~g} / \mathrm{L}\right.$ or $71 \mathrm{mM}$ at $\left.25^{\circ} \mathrm{C}\right)$ and insoluble in non-polar organic solvents (acetone, ethanol, and xylene) [5-9]. Depending on $\mathrm{pH}$, glyphosate forms cationic and anionic sites within its structure [10], having a zwitterionic behavior from $\mathrm{pH} 1$ to 10 [11]. 
The herbicidal activities of glyphosate were discovered in 1970 by John Franz and his co-workers at Monsanto [12]. Worldwide use of glyphosate in agriculture rose 13.3-fold, from 43 million kg in 1994 to 747 million $\mathrm{kg}$ in 2014 [2]. Currently, glyphosate is used in more than 130 countries, with a total global consumption estimated at over 825 million $\mathrm{kg}[13,14]$. Glyphosate is widely used in agriculture because of its ability to control perennial weed species, overwintering rhizomes and tubers, its ability to bind to soil colloids, and to introduce transgenic, glyphosate-resistant crops $[15,16]$. Under environmental conditions, glyphosate can be quickly degraded to aminomethylphosphonic acid (AMPA), the main metabolite, and glyoxylate by microorganisms, physical and chemical degradation, or photodegradation [17-19]. As previously mentioned about the heavy agricultural use, glyphosate can accumulate in the environment, migrate into soil and aquatic system, and be detected in plant products [20-23].

There are reports presenting evidence of human exposure to glyphosate [24,25]; and some even addressing the impact of the glyphosate residues on human health. In this context, a correlation was established between the increased glyphosate use and various human diseases such as kidney damage, attention-deficit, hyperactivity disorder (ADHD), autism, Alzheimer's and Parkinson's diseases [26]. Literature also indicates that glyphosate may contribute to the development of cancer in humans and animals [27]. Different international agencies including the European Food Safety Authority (EFSA), the International Agency for Research on Cancer (IARC), or the US Environmental Protection Agency (US EPA), have evaluated the carcinogenicity of glyphosate [28]. In March 2015, an assessment by IARC concluded that glyphosate is probably carcinogenic to humans (group 2A) [29]. Subsequently, the development of an analytical method to detect glyphosate proved to be crucial, and that in order to control harmful pollutants in various environments such as surface and ground water, agricultural systems, or soil.

Given the properties above-mentioned, maximum residue thresholds of glyphosate are established at the very low concentration especially for drinking water $(0.1 \mu \mathrm{g} / \mathrm{L}$ or $0.6 \mathrm{nM}$, in European countries) [30]. Liquid chromatography and gas chromatography coupled to mass spectrometry are traditional methods for glyphosate analysis [31-33]. However, the ionic and water-soluble proprieties of glyphosate make the analysis by HPLC advantageous over GC [34,35]. Capillary electrophoresis, coupled with mass electrophoresis was also implemented for the sensitive detection of glyphosate [36]. Although these are high sensitivity and selectivity methods, they present major drawbacks: complex behavior, specialized equipment, high operating costs, and time. To counteract the shortcomings of traditional analytical methods, developing a fast, simple, and low-cost method for glyphosate detection is a must. Noori et al. investigated an electrochemical sensor for glyphosate detection using Au electrode for amperometric measurements [37]. This method was successful in direct detection of glyphosate in drinking water without sample preparation or electrode modification, with a limit of detection (LOD) of $2 \mu \mathrm{M}$. In 2019, Mirmohseni et al. developed a sensitive layer based on a mixture of polydimethylsiloxane and acrylic polymer, which was coated on the surface with Au-coated quartz crystal chips for glyphosate detection using a quartz crystal nanobalance [38]. The calibration was obtained in the range of $0.2-8.6 \mathrm{mg} / \mathrm{L}(1.2-51 \mu \mathrm{M})$ with a LOD of $1.28 \mathrm{mg} / \mathrm{L}(7.6 \mu \mathrm{M})$. Recently, reports were published on a sub-nanomolar glyphosate optical sensor [39]. It is based on the functionalization of particle with enzyme, which can complex the analyte. 


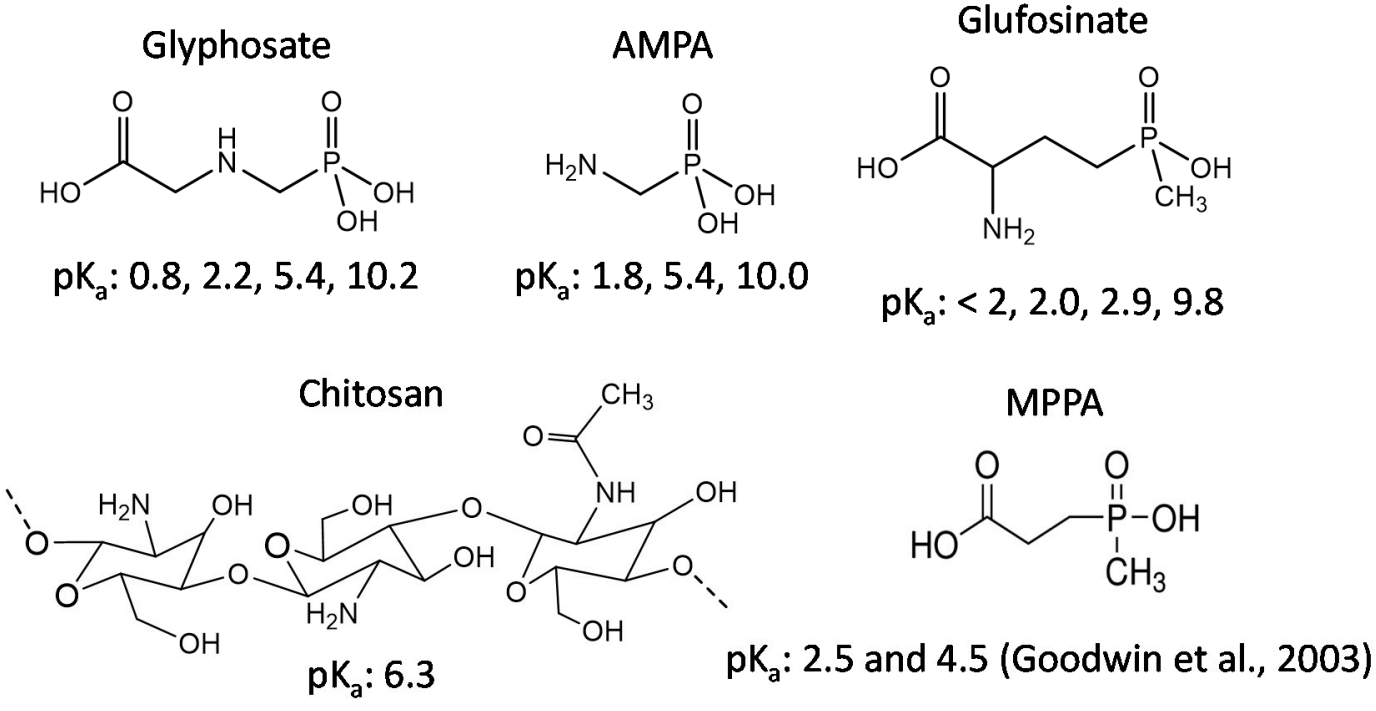

Figure 1. Structures and $\mathrm{pK}_{\mathrm{a}}$ of glyphosate, chitosan (CS), and other studied compounds (molar mass of glyphosate: $169.07 \mathrm{~g} / \mathrm{mol}$; aminomethylphosphonic acid (AMPA): $111.04 \mathrm{~g} / \mathrm{mol}$; glufosinate: 181.13 g/mol; 3-methyl-phosphinico-propionic acid (MPPA): 152.09 g/mol) [40].

The surface plasmon resonance (SPR) seems very promising for glyphosate detection with potential benefits such as easy operation, high sensitivity, and reliability. From the Kretschmann's configuration, the surface plasmon is obtained when an electromagnetic source interacts with free electrons on the interface between the thin metallic film and the dielectric media, which leads to the creation of an electromagnetic wave, propagating along the surface of the thin metal layer [41-43]. It is important to note that SPR only occurs when the momentum of the incoming light is equal to the momentum of the plasmon [41]. Such occurrence strongly depends on the changes of the refractive index near the Au-coated surface namely on the binding of molecules at the surface [44]. The SPR technique has received great attention in the field of sensor development for environmental monitoring (gas sensor, screening of trace elements or pesticides) [41,45-47]. The low-cost SPR instrumentation, based on fiber-optic, is still under development [48,49], and would be used for the on-field detection. The combination of active layers such as polyethylene, $\mathrm{MoS}_{2}$, and CS with SPR is capitalized on for sensitive detection of small molecules [46,49,50].

Chitosan ((1-4)-linked 2 acetamido-2-deoxy- $\beta$-D-glucan) (CS) is a linear cationic polysaccharide mainly produced by alkaline N-deacetylation of chitin shell from shrimps and other crustaceans [51,52]. CS offers many special characteristics including good film-forming, biodegradability, biocompatibility, low cost, non-toxicity, and good absorption properties. Due to its amine and hydroxyl groups, CS is suitable in potential applications for wastewater treatment, selective separation, and sensor development $[53,54]$. A process of cross-linking is typically applied to ensure the stable effectiveness of CS for the sorption and regeneration process. The selection of the type of the cross-linker and the reaction conditions can target the active site and the rate, respectively. The epichlorohydrin (EPI) is a cross-linking agent of $\mathrm{OH}$ groups of $\mathrm{CS}$, while glutaraldehyde (GA) is reactive with primary amine functional groups [55-57]. CS is considered as a promising material for SPR sensor development to be applied in various fields [46,58].

The scope of this study is the capability of CS thin film as a probe for sensitive and selective glyphosate detection by SPR for further on-field detection. Graphene oxide (GO) and zinc oxide $(\mathrm{ZnO})$ nanoparticles have excellent electrical and optical properties. They were hence selected for incorporation into CS to improve the sensitivity and selectivity of glyphosate sensor [59-62]. EPI and GA were used as cross-linkers under different conditions. Various parameters involved in the glyphosate detection were investigated and optimized to enhance the sensor selectivity. The SPR sensor selectivity was evaluated by comparing its behavior to other compounds containing similar 
structure and functional groups such as AMPA, glufosinate, and 3-methyl-phosphinico-propionic acid (MPPA), one of the glufosinate metabolites (Figure 1) [40,42].

\section{Kinetic and Equilibrium Interaction Models}

Different types of models can be used to describe interactions between glyphosate and the CS/ZnO sensing layer such as surface complex model $[63,64]$. Overall sorption reaction can be written as:

$$
>\mathrm{S}+\mathrm{nA} \leftrightarrows>\mathrm{SA}_{\mathrm{n}} \quad \mathrm{K}_{\mathrm{LF}, \mathrm{n}}=\frac{\left\{>\mathrm{SA} A_{\mathrm{n}}\right\}}{\{>\mathrm{S}\}|\mathrm{A}|^{\mathrm{n}}}
$$

where $\{>\mathrm{S}\}$ represents the concentration $(\mathrm{mol} / \mathrm{g})$ of the surface sites, which can be either amine groups of CS or hydroxyl groups of $\mathrm{CS}$ or $\mathrm{ZnO},|\mathrm{A}|$ the activity of the aqueous molecule interacting with the surface, and $\mathrm{K}_{\mathrm{LF}, \mathrm{n}}$ the thermodynamic constant.

Originally, this general model was developed to study the equilibrium for reversible sorption at solid-gas interfaces [64].

This general model has been extended in solution by taking into account the surface reactivity, such as surface acidity, surface complex formation or ion exchange, and aqueous speciation at equilibrium (see for more details Sigg et al., Charrière et al. [64,65]). From this model, different relationships, such as the Langmuir-type, Freundlich-type and Langmuir-Freundlich-type ones, can be deduced. They have been very often used for fitting reversible interactions at solid-liquid interfaces, at equilibrium.

The Langmuir-type model corresponds to the case of $n=1$, by assuming homogeneous binding surface sites without any attraction or repulsion force, for which one monolayer can be formed. For example, we can consider the following reaction for a 1:1 surface complex (charges are not written):

$$
>\mathrm{S}-\mathrm{XH}+\mathrm{A} \leftrightarrows>\mathrm{S}-\mathrm{XA}+\mathrm{H} \quad \mathrm{K}_{\mathrm{LF}, 1}=\mathrm{K}_{\mathrm{L}}=\frac{\{>\mathrm{S}-\mathrm{XA}\}|\mathrm{H}|}{\{>\mathrm{S}-\mathrm{XH}\}|\mathrm{A}|}
$$

In that case, $\mathrm{K}_{\mathrm{L}}$, the Langmuir-type coefficient depends on the acidity constants, the proton activity, the surface complexation constants, and the aqueous speciation of the sorbate, e.g., glyphosate (for more information, see Sigg et al., 2014 [64]).

If $\mathrm{n} \neq 1$, the Langmuir-Freundlich-type model corresponds either to the case of a reaction, for which $n$ A molecules can react with one surface site or to heterogeneous surface behavior over the entire concentration range up to surface site saturation [66]. The Freundlich-type model refers to heterogeneous distribution or to the Langmuir-Freundlich-type model for which $\mathrm{K}_{\mathrm{LF}, \mathrm{n}}[C]<<1$.

A pseudo-first-order kinetic relationship corresponding to relation (3) and the three different equilibrium isotherm models, Langmuir-type (4), Freundlich-type (5) and Langmuir-Freundlich-type (6) ones, were applied to the data of SPR sensor at constant $\mathrm{pH}$ value fixed [63-65,67-69]:

$$
\begin{gathered}
\frac{\mathrm{d} \Delta R}{d t}=\mathrm{k}_{\mathrm{a}}[C]\left(\Delta R_{\max }-\Delta R\right)-\mathrm{k}_{\mathrm{d}} \Delta R \quad \mathrm{~K}_{\mathrm{A}}=\frac{\mathrm{k}_{\mathrm{a}}}{\mathrm{k}_{\mathrm{d}}} \\
\Delta R=\frac{\Delta R_{\max } \mathrm{K}_{\mathrm{L}}[C]}{\left(1+\mathrm{K}_{\mathrm{L}}[C]\right)} \\
\Delta R=\mathrm{K}_{\mathrm{F}}[C]^{\mathrm{n}} \\
\Delta R=\frac{\Delta R_{\max } \mathrm{K}_{\mathrm{LF}, \mathrm{n}}[C]^{\mathrm{n}}}{\left(1+\mathrm{K}_{\mathrm{LF}, \mathrm{n}}[C]^{\mathrm{n}}\right)}
\end{gathered}
$$

with $\Delta R$ : variation in SPR angle (mdeg); $\Delta R_{\max }$ the maximum of the change in SPR angle (mdeg); $\mathrm{d} \Delta R / d t$ the rate of change of the SPR signal; $[C]$ the glyphosate concentration $(\mathrm{M}) ; \mathrm{k}_{\mathrm{a}}\left(\mathrm{M}^{-1} \mathrm{~s}^{-1}\right)$ and $\mathrm{k}_{\mathrm{d}}\left(\mathrm{s}^{-1}\right)$ values of binding and dissociation rate constants, respectively; $\mathrm{K}_{\mathrm{A}}\left(\mathrm{M}^{-1}\right)$ the forward coefficient at 
equilibrium, respectively; $\mathrm{K}_{\mathrm{L}}$ the Langmuir-type coefficient $\left(\mathrm{M}^{-1}\right) ; \mathrm{K}_{\mathrm{F}}$ the Freundlich-type coefficient (mdeg $\left.\mathrm{M}^{-\mathrm{n}}\right) ; \mathrm{K}_{\mathrm{LF}, \mathrm{n}}$ the Langmuir-Freundlich-type coefficient $\left(\mathrm{M}^{-\mathrm{n}}\right)$; $\mathrm{n}$ : the "heterogeneity" index.

\section{Material and Methods}

\subsection{Chemicals and Instrumentation}

CS (30000 g/mol, degree of deacetylation $>90 \%$ ) was obtained from Glentham Life Sciences (UK). $\mathrm{ZnO}(>97 \%,<50 \mathrm{~nm}), \mathrm{GO}\left(2 \mathrm{mg} / \mathrm{mL}\right.$, dispersion in $\left.\mathrm{H}_{2} \mathrm{O}\right)$, glyphosate (analytical standard), glufosinate (analytical standard), AMPA (analytical standard), EPI (analytical standard), GA (25\%), acetic acid ( $\geq 99 \%), \mathrm{H}_{2} \mathrm{O}_{2}$ solution (30\%), $\mathrm{NH}_{4} \mathrm{OH}(99.98 \%), \mathrm{NaCl}(\geq 99.5 \%), \mathrm{HCl}(37 \%)$, and $\mathrm{NaOH}(>98 \%)$ were purchased from Sigma-Aldrich (France). All reagents were used without further purification. Ultra-pure water (UPW) was used for all solution preparation $\left(18.2 \mathrm{M} \Omega . \mathrm{cm}\right.$ at $\left.25^{\circ} \mathrm{C}\right)$.

The Au sensor slides called later Au chips (SPR102-AU, $12 \mathrm{~mm} \times 20 \mathrm{~mm}$, BioNavis Ltd., Tampere, Finland) were taken from Bionavis ${ }^{\mathrm{TM}}$.

The polymer film was coated on the Au chip with a SPIN150i spin coater (POLOS spin coaters, Ingoldstadt, Germany).

The real-time detection of glyphosate in aqueous solution was carried out by MP-SPR Navi ${ }^{\mathrm{TM}}$ 200 OTSO (BioNavis Ltd., Tampere, Finland) using independent wavelength measurements (670 and $785 \mathrm{~nm}$ ) with fluidic channels (standard flow-cell SPR Navi 200, SPR301).

FTIR spectra were measured at room temperature using a FTIR spectrometer (Spectrum 400, Perkin Elmer, Waltham, MA, USA) coupled to an attenuated total reflectance sampling accessory of diamond contact crystal. Recordings were obtained with a spectral width between 600 and $4000 \mathrm{~cm}^{-1}$ at a resolution of $4 \mathrm{~cm}^{-1}$.

AFM was used to investigate the surface morphology of the polymer films. Measurements were carried out using a Smart SPM-TM-1000 (AIST-NT, Novato, CA, USA) at Laboratoire de Chimie de Coordination (LCC, Toulouse, France). A MikroMasch tip HQNSC15-ALBs (silicon with an aluminum coating) was measured in tapping mode within a $5 \mu \mathrm{m} \times 5 \mu \mathrm{m}$ sample area at a frequency of 265-400 $\mathrm{kHz}$ and a force constant $\mathrm{K}=40 \mathrm{~N} / \mathrm{m}$.

The contact angles of the polymer films were recorded using a Tracker ${ }^{\mathrm{TM}}$ Automatic Drop Tensiometer (TECLIS Scientific, Civrieux d'Azergues, France). Measurements were carried out in accordance with the static "sessile drop" mode, using UPW as liquid phase ( $8.0 \mu \mathrm{L}$ drops, $\mathrm{n}=3$ ), and then, contact angle values were measured for each sample.

\subsection{Preparation of Thin Film}

The Au layer of the chip was cleaned before use to ensure the stability and reproducibility of measurements made with the SPR instruments. An Au chip was placed in the boiling solution containing $\mathrm{NH}_{4} \mathrm{OH}(30 \%), \mathrm{H}_{2} \mathrm{O}_{2}(30 \%)$, and UPW prepared with a ratio of 1:1:5 (v:v:v) at $80-90{ }^{\circ} \mathrm{C}$. After $15 \mathrm{~min}$, the chip was removed from the solution and immediately rinsed with UPW. Afterward, it was dried under a stream of $\mathrm{N}_{2}$, and then the slide was dried in air. Finally, the Au chip was treated by $\mathrm{UV}_{-} \mathrm{O}_{3}$ for about $10 \mathrm{~min}$. Experiments were started right after this treatment.

Preparation of $1.3 \%$ CS solution and SPR chip is summarized in Figure 2. Each CS nanocomposite solution was placed in an ultrasonic bath for $30 \mathrm{~min}$. After spin coating, the cross-linking process was set to proceed under different conditions, followed by washing with UPW. FTIR, AFM and contact angles were used to investigate the characterization of the sensor surface. 


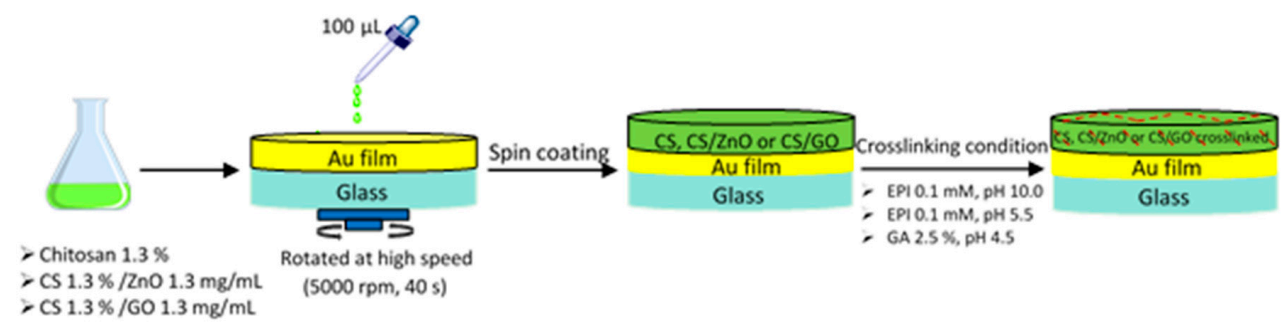

Figure 2. Schema of the preparation procedure for SPR sensor with different experimental conditions.

\subsection{Procedure of the Analysis}

The concept of SPR sensor for the real-time determination of glyphosate was performed with four simultaneous measurements in two fluidic channels.

All measurements were carried out in a flow-through mode with a flow rate of $40 \mu \mathrm{L} / \mathrm{min}$ at $20.3^{\circ} \mathrm{C}$. The dead volume was estimated at around $97 \mu \mathrm{L}$, which corresponds to around $156 \mathrm{~s}$ between injection and the cell output. After inserting the SPR sensor into BioNavis system, a solution of $1 \mathrm{mM}$ $\mathrm{HCl}$ was injected into the cell to wash the sensor surface. The sensor was stabilized in UPW after having reached a stable baseline. The UPW signal was recorded as a blank. Glyphosate solutions were then injected into the SPR system. The SPR signals vs. time at different glyphosate concentrations were recorded. Once the SPR signal reached a steady-state, the sensor was washed and stabilized to obtain a new baseline. Stabilization-sorption-washing steps were repeated for each glyphosate sample. The weighted centroid function of the SPR position (angle) was used to quantitatively determine the glyphosate sorption. Measurements performed at $670 \mathrm{~nm}$ showed a higher sensitivity than at $785 \mathrm{~nm}$, hence the selection of this wavelength for qualification.

\subsection{Evaluation of CS/ZnO SPR Sensor Response}

In order to check the method reproducibility, three different SPR sensors were fabricated in the same conditions. The aqueous solution of glyphosate $(0.30 \mu \mathrm{M})$ was then applied to three sensors. The SPR responses were used to evaluate the reproducibility of the SPR sensors.

To evaluate the reusability of the glyphosate SPR sensor, three stabilization-sorption-extraction cycles were repeated on the same SPR sensor with the aqueous solution of glyphosate $(0.06 \mu \mathrm{M})$.

Limit of detection (LOD) and limit of quantification (LOQ) were estimated under the optimized conditions according to the relationships [70]:

$$
\begin{gathered}
L O D=\frac{3 s_{\text {blank }}}{\text { slope }} \\
L O Q=\frac{10 s_{\text {blank }}}{\text { slope }}
\end{gathered}
$$

where $s_{\text {blank }}$ is the standard deviation of the blank measurements in the absence of glyphosate, and the slope corresponds to the regression line between SPR signal and glyphosate concentration over the linear range.

\subsection{Statistical Analysis}

The descriptive statistic was used to describe the basic features of the data in the study. All data presented in this work are the mean of three different SPR sensors, and the standard deviation was calculated as the square root of the variance of the three responses. 


\section{Results and Discussion}

\subsection{Characterization of CS-Based Nanocomposite Films}

The thin films of CS, CS/GO, and CS/ZnO composite deposited onto the Au chips and cross-linked by GA were characterized by FTIR (Figure 3). The FTIR spectrum of CS film showed the main absorption bands at $3447 \mathrm{~cm}^{-1}$ assigned to the stretching vibrations of $-\mathrm{N}-\mathrm{H}$ and $\mathrm{O}-\mathrm{H}$ bonds [71,72] corresponding to free, intra-, and inter-molecular H-bonded groups (alcohol, amine, and amide). The vibrations related to the stretching of the bond $\mathrm{C}-\mathrm{H}$ of $-\mathrm{CH},-\mathrm{CH}_{2}$, and $-\mathrm{CH}_{3}$ groups of $\mathrm{CS}$ could be characterized by the band in the region of $2916 \mathrm{~cm}^{-1}$ [73]. In the range between 1700 and $1500 \mathrm{~cm}^{-1}$, the FTIR spectra revealed the vibrations of several bonds. The vibration intensity and position depend on the cross-linking rate and the acetylation degree of CS.

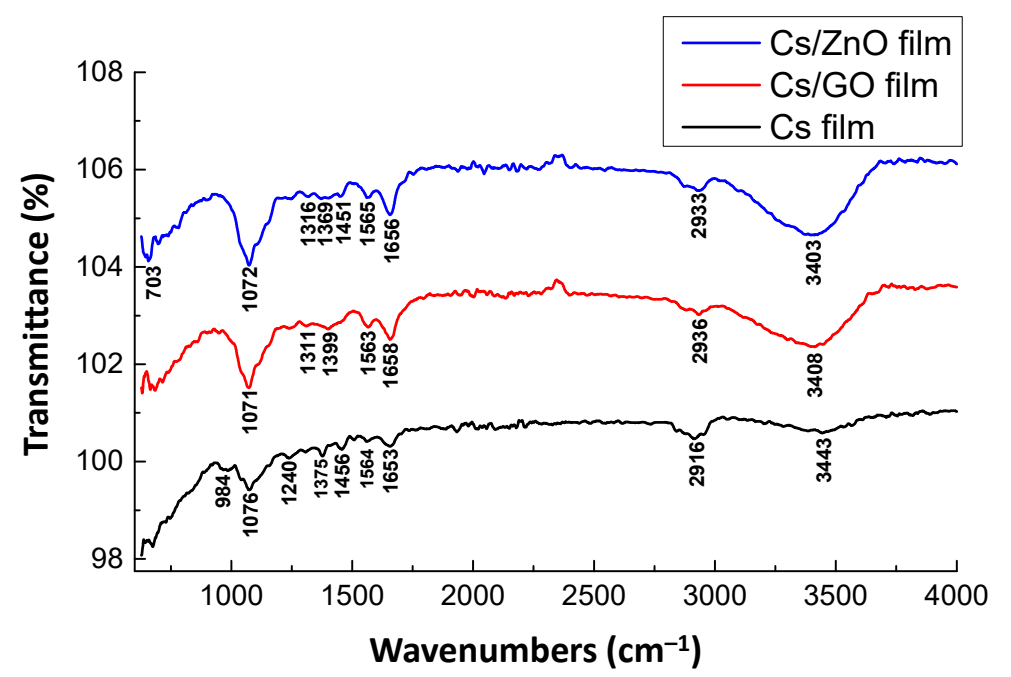

Figure 3. FTIR spectra of CS, CS/GO, and CS/ZnO composite thin film cross-linked by GA.

The band close to $1653 \mathrm{~cm}^{-1}$ can be attributed to the stretching vibration of the $\mathrm{C}=\mathrm{O}$ of the amide group [71,72] and of the imine bond $(\mathrm{C}=\mathrm{N})$ formed by a reaction between $\mathrm{GA}$ and amino groups. The absorption peak near $1564 \mathrm{~cm}^{-1}$ corresponds to the bending vibration of $-\mathrm{N}-\mathrm{H}$ bond from both primary amine and secondary amine groups [71,72]. The peak shifts depending on the ratio of free primary amine (not cross-linked by GA) site to amide group. The $-\mathrm{N}-\mathrm{H}$ binding vibration of primary amine group of CS is normally centered at $1595 \mathrm{~cm}^{-1}$ and those of amide group of chitin are observed at $1565 \mathrm{~cm}^{-1}$ [74].

The wide band centered at $1076 \mathrm{~cm}^{-1}$ can be assigned to the vibrations: $\mathrm{C}-\mathrm{O}-\mathrm{C}, \mathrm{C}-\mathrm{OH}$, and $\mathrm{C}-\mathrm{CH}_{2}$ stretching and $\mathrm{CH}, \mathrm{CH}_{2}$, and $\mathrm{CH}_{3}$ bending [75]. The band at $984 \mathrm{~cm}^{-1}$ is associated to the aliphatic amine and the stretching vibration of CS ring [76]. In the case of CS/GO and CS/ZnO composite thin film, the presence of the most typical absorption peaks of CS was also observed in the FTIR spectrum of the composites. However, the peak in the range of $3400 \mathrm{~cm}^{-1}$ assigned to the stretching vibration of $-\mathrm{OH}$ and $-\mathrm{NH}_{2}$ groups shifted to a lower position and became broader and of higher intensity, indicating a strong interaction between these groups and the oxides ( $\mathrm{GO}$ and $\mathrm{ZnO}$ ). The characteristic bands of the $\mathrm{C}-\mathrm{H}$ symmetric and antisymmetric stretching vibrations of $\mathrm{CH}_{2}$ and $\mathrm{CH}_{3}$ groups were shifted to higher wavenumber of 2933 and $2936 \mathrm{~cm}^{-1}$ for composites, which indicates a slight change of the functional group ratio due to the presence of oxides. Similarly, the vibration of $C=O$ and $C=N$ at $1653 \mathrm{~cm}^{-1}$ was shifted toward higher wavenumber and increased in the presence of nano $\mathrm{ZnO}$ or GO, which confirms that the amine and amide groups of CS were involved in the formation of linkage between CS and GO or ZnO. These FTIR results show the successful formation of composites between $\mathrm{CS}$ and $\mathrm{GO}$ or $\mathrm{CS}$ and $\mathrm{ZnO}$. 
The hydrophobic/hydrophilic nature of chips was evaluated by the contact angle technique at ambient conditions. Contact angle values for $\mathrm{Au}, \mathrm{CS}, \mathrm{CS} / \mathrm{GO}$, and CS/ZnO composite thin films are $91.2 \pm 1.9,47.3 \pm 1.6,60.9 \pm 1.8$, and $62.0 \pm 0.6$, respectively (Figure 4). Contact angle values decreased after coating by CS and its nanocomposites due to CS amino and hydroxyl, hydrophilic functional groups, indicating that hydrophilic films on the Au chip were formed. The increase in the contact angle value of CS nanocomposites compared to CS indicates that the attachment of GO or $\mathrm{ZnO}$ causes an increment in the hydrophobic properties of films. These results show that the CS, CS/GO, and CS/ZnO film could be formed on the Au chip.

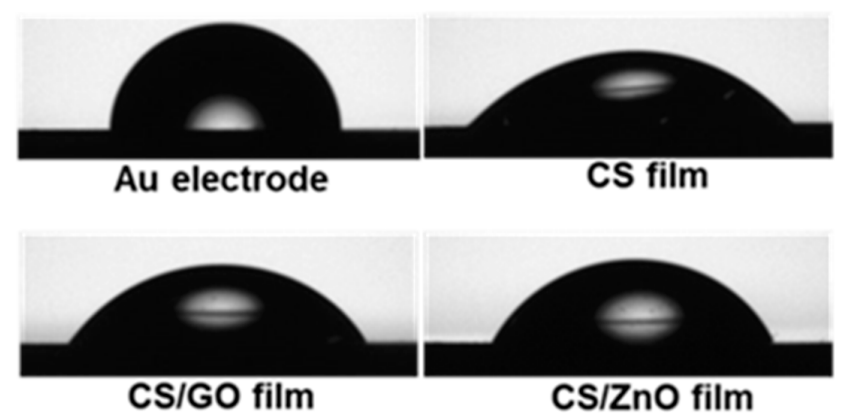

Figure 4. Contact angle measurements on Au electrode, CS, CS/GO, and CS/ZnO composite thin film cross-linked by GA.

Surface morphologies of various modified chips with CS, CS/GO, and CS/ZnO composite thin films were investigated by AFM (Figure 5). The roughness of the surface was measured using AFM analysis in the root-mean-square (RMS). The Au chip considered as reference was rough with a calculated RMS value of $1.85 \mathrm{~nm}$. The AFM pictures showed a relatively smooth, compact, and homogeneous surface after coating with CS and its nanocomposites (Figure 5). The RMS values of CS, CS/GO, and CS/ZnO composite thin films were $0.946,0.747$, and $0.853 \mathrm{~nm}$, respectively. In addition to that, very small bright spots corresponding to $\mathrm{ZnO}$ nanoparticles in the case of $\mathrm{CS} / \mathrm{ZnO}$ film could be observed. These changes confirm that the CS and its nanocomposites film could be successfully achieved on the Au chips.

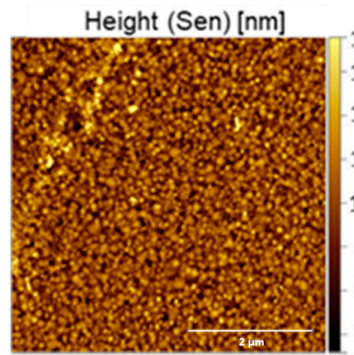

Au film

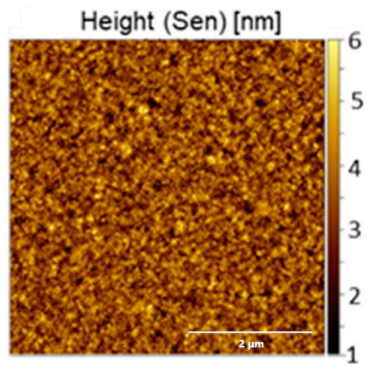

CS/GO film

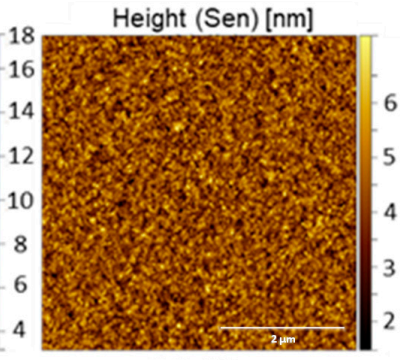

CS film

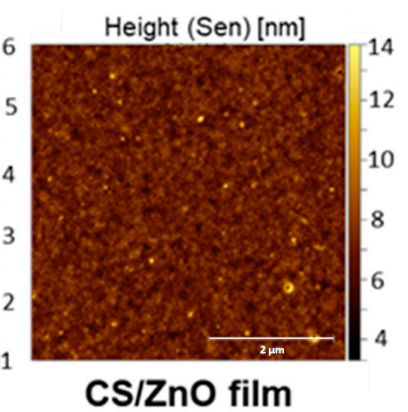

Figure 5. AFM images of Au electrode, CS, CS/GO, and CS/ZnO composite thin films cross-linked by GA. 


\subsection{Sensitivity of CS-Based Nanocomposite Films for Glyphosate Detection}

The experiments were performed to investigate the CS-based composites for enhancing the sensitivity and selectivity for two glyphosate concentrations, 0.06 and $0.30 \mu \mathrm{M}$, at pH 5.5 (Figure 6). The highest increase in the SPR angle change was recorded by CS/ZnO SPR sensor compared to CS (2 times) and CS/GO (1.5 times) ones. With the CS SPR sensor, the sorption of glyphosate depended only on amine and hydroxyl groups of CS. The increase in the sorption for CS/ZnO SPR sensor could be explained by the complex formation between glyphosate and $\mathrm{ZnO}$ at the liquid-solid interface [77]. On the other hand, the incorporation of CS and $\mathrm{ZnO}$ nanoparticles was assumed to improve optical properties leading to enhance the sensitivity of CS/ZnO SPR sensor [62,78]. In the case of CS/GO SPR sensor, the optical properties of GO could not improve the glyphosate sorption because of the non-uniformity and cracks of the CS/GO composite coated on the Au chip. Consequently, the CS/ZnO SPR sensor was selected for further experiments.

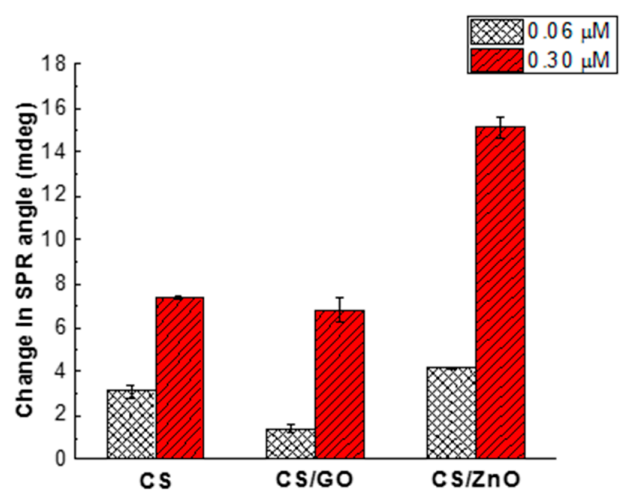

Figure 6. Sensitivity of glyphosate sorption via a change in angle on CS film alone, CS/GO, and CS/ZnO film cross-linked by GA for two glyphosate concentrations $(0.06$ and $0.30 \mu \mathrm{M})$, at pH 5.5.

\subsection{Effect of Cross-Linking Conditions on the Sensitivity of CS/ZnO Composite Films}

The sensitivity of three CS cross-linking conditions on the sorption capacity of the three SPR sensors was evaluated through SPR responses for two glyphosate solutions (0.06 and $0.30 \mu \mathrm{M})$ (Figure 7). Overall, CS/ZnO cross-linked in acidic conditions displayed a higher SPR response for glyphosate than the film cross-linked in alkaline conditions. The protonation of amino groups on cross-linked CS/ZnO thin film could explain it, since acidic conditions would increase the interactions between glyphosate and the receptor.

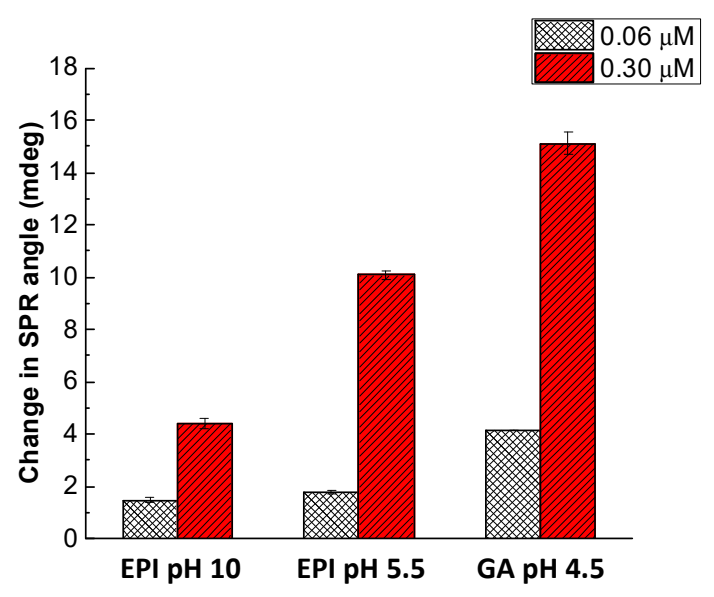

Figure 7. Glyphosate sorption onto CS/ZnO SPR sensor cross-linked for two glyphosate concentrations $(0.06$ and $0.30 \mu \mathrm{M})$, at $\mathrm{pH}$ 5.5. Experimental conditions: cross-linking for $2 \mathrm{~h}$ with $\mathrm{GA}(2.5 \%, \mathrm{pH} 4.5)$, EPI (0.1 mM, pH 10) at $40{ }^{\circ} \mathrm{C}$ or EPI $(0.1 \mathrm{mM}, \mathrm{pH} 5.5)$ at $40{ }^{\circ} \mathrm{C}$ followed by washing with UPW. 
Results showed higher values of SPR response for GA cross-linked SPR sensor than other SPR sensors. Some studies have also shown that the adsorption capacity of the CS cross-linked by GA was favored by the presence of amino groups leading to the improvement of the electrostatic and hydrophobic properties of CS $[79,80]$. In the case of SPR sensor cross-linked by EPI in acidic medium, the lower SPR response could be explained by the fact that amino groups are partially blocked $[79,81]$. For that reason, GA was selected as a cross-linker for CS/ZnO composite thin film at $\mathrm{pH}$ 4.5.

\subsection{Effect of $\mathrm{pH}$ on the Sorption Capacity of CS/ZnO Composite Films}

In this study, the different solutions were not buffered after addition of $\mathrm{HCl}$ or $\mathrm{NaOH}$. Buffering is a critical issue when studying the role of $\mathrm{pH}$, for buffer addition is not neutral for various reasons as discussed by many authors [82,83]. The first reason is the role of electrolyte used, which can interfere with the target molecule and modify its behavior as observed by some authors $[65,84,85]$. Moreover, buffering can hide some exchange processes due to the constant $\mathrm{pH}[84,85]$. The alternative would be to leave the $\mathrm{pH}$ free. In fact, different authors worked without buffer to avoid such drawback [86-88]. In this study, we decided to avoid such interactions by removing all buffering molecules.

As observed in Figure 8, the SPR response at steady state depends on $\mathrm{pH}$, decreasing from $\mathrm{pH} 4.0$ to 7.0, corresponding to a titration of the surface sites of $\mathrm{CS} / \mathrm{ZnO}$ film cross-linked by GA.

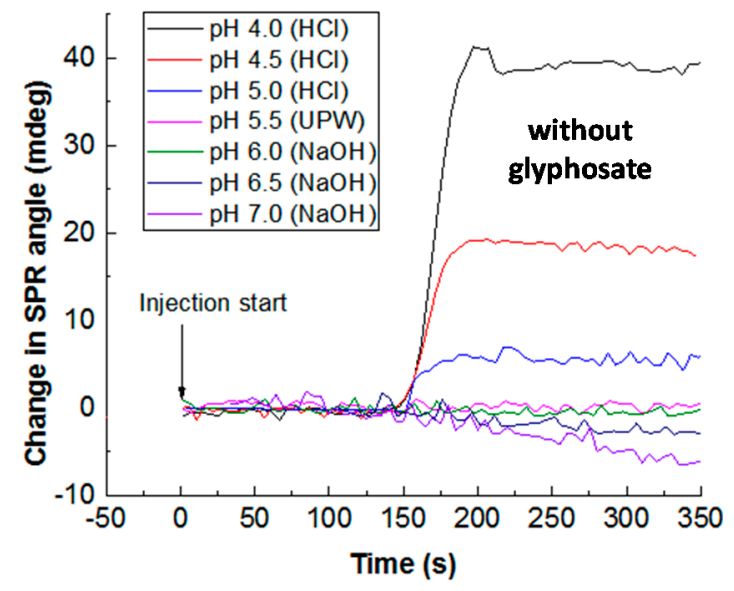

Figure 8. Role of $\mathrm{pH}$ without glyphosate in the change in SPR angle in the case of CS/ZnO film cross-linked by GA (dead time corresponds to around $156 \mathrm{~s}$ between injection and the cell output). Experimental conditions for each reported $\mathrm{pH}$ value: injection of UPW ( $\mathrm{pH}$ 5.5) before injection of a solution at given $\mathrm{pH}$ adjusted by $0.01 \mathrm{M} \mathrm{HCl}$ and $0.01 \mathrm{M} \mathrm{NaOH}$ into the SPR system.

The sorption of glyphosate at $0.30 \mu \mathrm{M}$ onto $\mathrm{CS} / \mathrm{ZnO}$ adsorbents was valuated from $\mathrm{pH} 4.0$ to 7.0 (Figure 9). The SPR response increased and then decreased after reaching a maximum $\mathrm{pH}$ value at 5.5. The interaction between the SPR sensor and glyphosate was controlled by the protonation/deprotonation of the CS and glyphosate [82]. The SPR sensor had lower sorption capacity when $\mathrm{pH}$ decreased from 5.5 to 4.0 , due to the protonation of glyphosate (see Figure 8). Meanwhile, most of the free amine groups on the CS molecule were still protonated in acid medium $\left(\mathrm{pH}<\mathrm{pK}_{\mathrm{a}}=6.3\right.$, for CS). When $\mathrm{pH}$ of the glyphosate solution increased from 5.5 to 7.0, the sorption amount of glyphosate on the SPR sensor significantly decreased for the SPR sensor, which could be explained by the deprotonation of amino groups. Moreover, aqueous $\mathrm{OH}^{-}$groups could compete with glyphosate, negatively charged under alkaline condition $[89,90]$. According to the result, $\mathrm{pH} 5.5$ was selected as the optimal $\mathrm{pH}$ in the following experiments. 


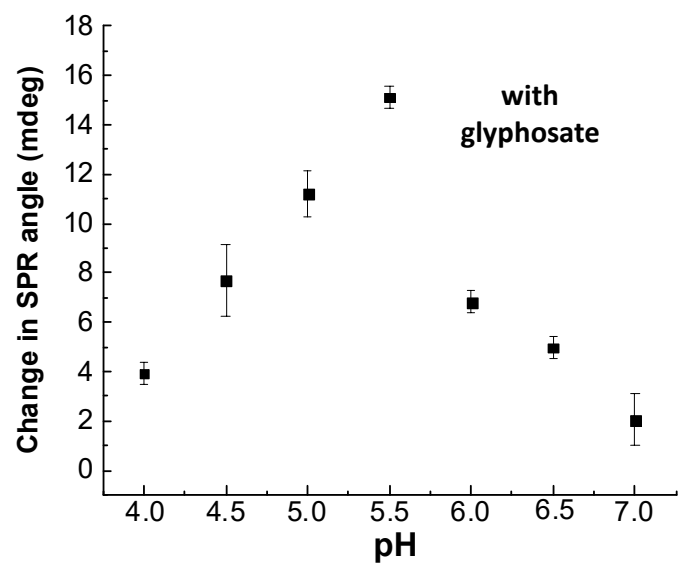

Figure 9. Role of $\mathrm{pH}$ (4.0 to 7.0) in the change in SPR angle in the case of CS/ZnO film cross-linked by GA in the presence of $0.30 \mu \mathrm{M}$ glyphosate (dead time corresponds to around $156 \mathrm{~s}$ between injection and the cell output). Experimental conditions: (i) first, injection of a non-buffered solution at a given $\mathrm{pH}$ adjusted by $0.01 \mathrm{M} \mathrm{HCl}$ and $0.01 \mathrm{M} \mathrm{NaOH}$ without glyphosate into the SPR system to obtain a steady-state baseline, followed by the injection of the glyphosate solution at the same $\mathrm{pH}$, and the change in SPR angle corresponding to the effect of glyphosate with respect to the baseline before glyphosate injection; (ii) same procedure at another $\mathrm{pH}$ value.

\subsection{CS/ZnO SPR Sensor Response for Glyphosate at pH 5.5 and Ionic Strength (I) Effect}

Real-time responses of the sensor vs. aqueous solutions of glyphosate at different concentrations are reported in Figure 10. The increase in glyphosate concentration led to an increase in SPR sensor response. SPR signals of the sensor increased quickly when the glyphosate solution reached the sensor surface. The changes in SPR response were monitored in real-time and reached a steady state at about $250 \mathrm{~s}$ before desorption, which was obtained after the injection of UPW at pH 5.5. The total desorption was obtained after more than $450 \mathrm{~s}$.

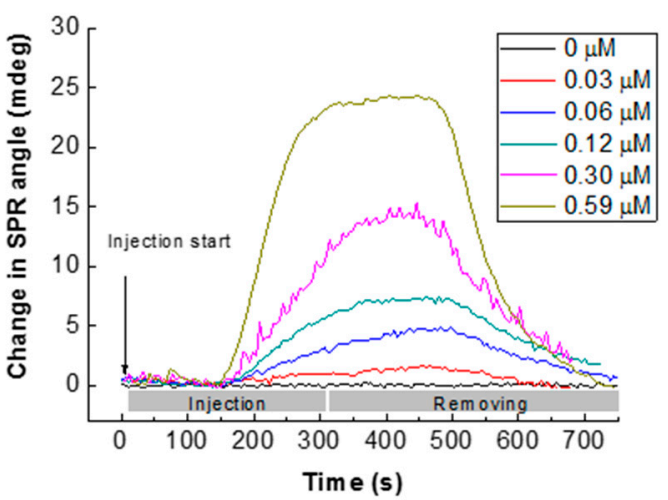

Figure 10. Typical sensorgrams of glyphosate sorption onto CS/ZnO SPR sensors for glyphosate concentration from 0 to $0.59 \mu \mathrm{M}$ (dead time corresponds to around $156 \mathrm{~s}$ between injection and the cell output).

Under optimal experimental conditions, CS/ZnO SPR sensors interacted with aqueous glyphosate solutions in the concentration range of $0-189 \mu \mathrm{M}$ at pH 5.5 (Figure 11a).

The SPR response showed the reasonable linearity of the sensor response vs. glyphosate concentration estimated in the range of $0-0.59 \mu \mathrm{M}$ with a regression coefficient $\left(R^{2}\right)$ value of 0.9935 (Figure 11b). In the investigated concentration range, the LOD and LOQ values of the CS/ZnO SPR sensor were calculated to be 0.008 and $0.027 \mu \mathrm{M}$, respectively. 

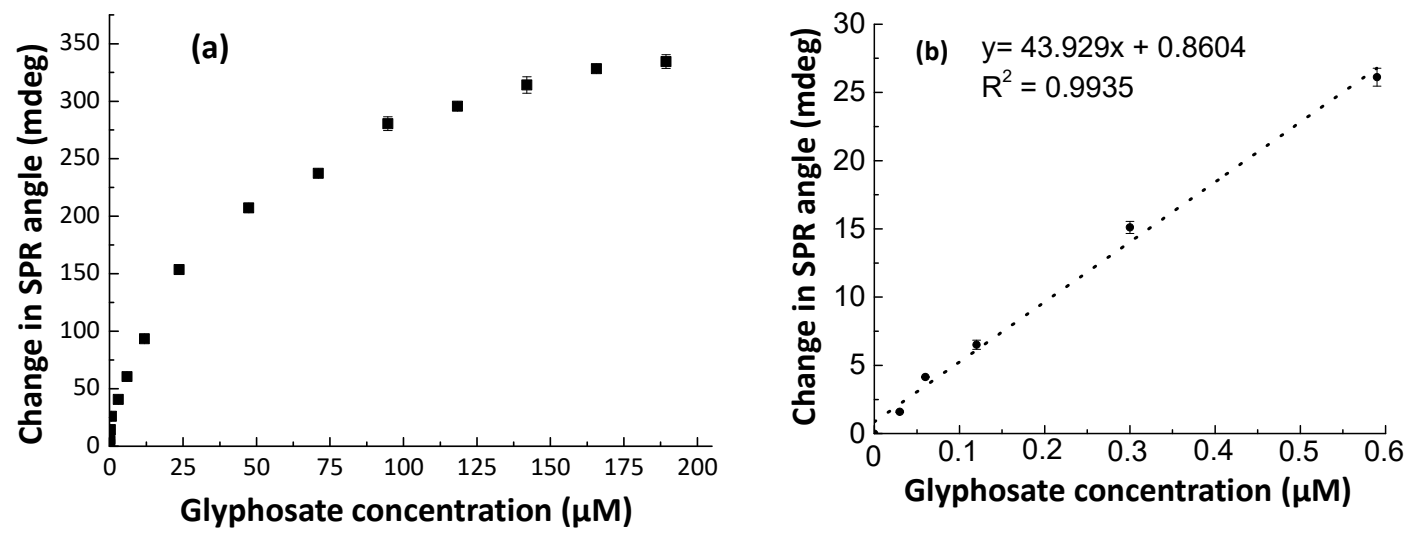

Figure 11. Glyphosate sorption onto CS/ZnO SPR sensors at pH 5.5: (a) full sorption isotherm of glyphosate; (b) calibration curve in the glyphosate concentration ranges between 0.03 and $0.59 \mu \mathrm{M}$.

The relative standard deviation (RSD) for three different CS/ZnO sensors was $5.2 \%$ at the glyphosate concentration of $0.30 \mu \mathrm{M}$, which corresponds to a good reproducibility. The RSD was about $4.6 \%$ for three stabilization-sorption-extraction cycles with the same sensor for the glyphosate solution of $0.06 \mu \mathrm{M}$, revealing thus the reusability of the sensor. Furthermore, the CS/ZnO sensor exhibited an excellent analytical performance in terms of sensitivities compared to previous studies related to optical methods for glyphosate detection (Table 1).

Table 1. Comparison of the CS/ZnO sensor with other optical methods for glyphosate detection.

\begin{tabular}{cccc}
\hline Sensor & Linear Range & LOD & Ref. \\
\hline Colloidal Ag nanoparticles/SERS a & $237-350 \mu \mathrm{M}$ & $10 \mu \mathrm{M}$ & {$[91]$} \\
AgNPs b/SERS & - & $5.3 \mu \mathrm{M}$ & {$[92]$} \\
Cu doped poly(vinyl) alcohol)) nanofiber/colorimetric & $0.59-2958 \mu \mathrm{M}$ & $0.59 \mu \mathrm{M}$ & {$[93]$} \\
Carbon dot labelled antibodies/magnetic NPs/fluorescence & $0.059-473 \mu \mathrm{M}$ & $0.047 \mu \mathrm{M}$ & {$[94]$} \\
2-mercapto-5-nitrobenzimidazole capped AgNPs & $399-517 \mathrm{nM}$ & $17.1 \mathrm{nM}$ & {$[95]$} \\
(MNBZ-AgNPs)/Mg ${ }^{2+} /$ colorimetric & - & $0.005 \mu \mathrm{M}$ & {$[96]$} \\
Hydrophobin-EPSPS c Fusion Protein/Spectrophotometer. & $0-0.59 \mu \mathrm{M}$ & $0.008 \mu \mathrm{M}$ & This work \\
CS/ZnO/SPR &
\end{tabular}

a: Surface-enhanced Raman spectroscopy; ${ }^{\text {b: }}$ Silver nanoparticles; ${ }^{c}$ : Enzyme: 5-enolpyruvylshikimate-3phosphate synthase.

The effect of ionic strength, $\mathrm{I}$, $\mathrm{NaCl}$ as electrolyte) on the glyphosate behavior in the presence of the $\mathrm{CS} / \mathrm{ZnO}$ SPR sensor was investigated for I range from 0 to $2 \mathrm{mM}$ at pH 5.5 (Figure 12). Overall, the SPR response strongly decreased with the increase in I. At higher I value, no such change was observed.

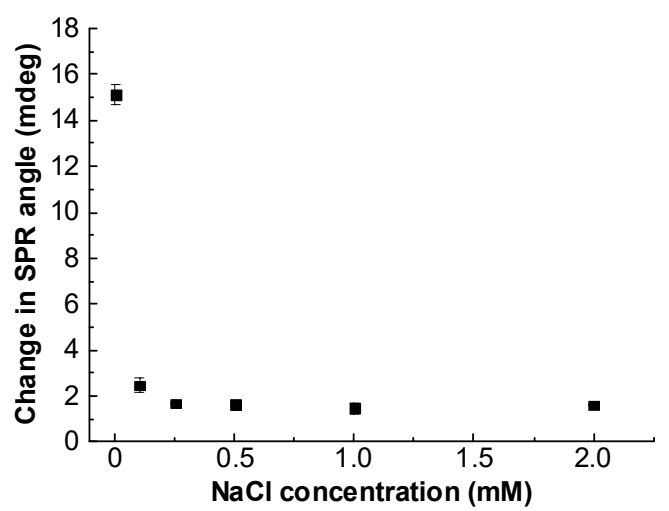

Figure 12. Effect of ionic strength ( $\mathrm{NaCl}$ concentration) on the glyphosate sorption onto $\mathrm{CS} / \mathrm{ZnO}$ SPR sensor at $0.30 \mu \mathrm{M}$ glyphosate and $\mathrm{pH} 5.5$. 


\subsection{Sorption Mechanisms}

$\mathrm{CS} / \mathrm{ZnO}$ SPR responses were used to estimate kinetic and isotherm parameters based on Equations (2) to (5) from data reported in Figure 11 and Table 2. Parameters for the pseudo-first-order kinetics were estimated with a $R_{\max }$ value of 340 (mdeg) obtained from experimental data. The experiment showed that the estimated value of the binding rate constant $\mathrm{k}_{\mathrm{a}}\left(1.9 \times 10^{3} \mathrm{M}^{-1} \cdot \mathrm{s}^{-1}\right)$ was higher than the value of the dissociation rate constant $\mathrm{k}_{\mathrm{d}}\left(5.8 \times 10^{-4} \mathrm{~s}^{-1}\right)$. The estimated $\mathrm{K}_{\mathrm{A}}$ value was very high meaning that the affinity between the $\mathrm{CS} / \mathrm{ZnO}$ film and glyphosate was very strong for such experimental conditions.

Table 2. Estimated parameters of kinetic law and sorption isotherm relationships in the case of glyphosate sorption onto CS/ZnO SPR sensors at pH 5.5 (see relationships (3) to (6)).

\begin{tabular}{|c|c|c|c|c|c|c|c|c|c|}
\hline \multicolumn{10}{|c|}{ Pseudo-First-Order Kinetics } \\
\hline \multicolumn{2}{|c|}{$\mathrm{k}_{\mathrm{a}}\left(\mathrm{M}^{-1} \mathrm{~s}^{-1}\right)$} & \multicolumn{2}{|c|}{$\mathrm{k}_{\mathrm{d}}\left(\mathrm{s}^{-1}\right)$} & \multicolumn{2}{|c|}{$\mathrm{K}_{\mathrm{A}}\left(\mathrm{M}^{-1}\right)$} & \multicolumn{4}{|c|}{$\mathrm{R}^{2}$} \\
\hline \multicolumn{2}{|c|}{$1.9 \times 10^{4}$} & \multicolumn{2}{|c|}{$5.8 \times 10^{-4}$} & \multicolumn{2}{|c|}{$3.3 \times 10^{7}$} & \multicolumn{4}{|c|}{0.998} \\
\hline \multicolumn{10}{|c|}{ Equilibrium Isotherm Models } \\
\hline \multicolumn{3}{|c|}{ Langmuir-type } & \multicolumn{3}{|c|}{ Freundlich-type } & \multicolumn{4}{|c|}{ Langmuir-Freundlich-type } \\
\hline $\begin{array}{l}\Delta \mathrm{R}_{\max } \\
\text { (mdeg) }\end{array}$ & $\mathrm{K}_{\mathrm{L}}\left(\mathrm{M}^{-1}\right)$ & $\mathrm{R}^{2}$ & $\mathrm{n}$ & $\begin{array}{c}\mathrm{K}_{\mathrm{F}} \\
\left(\mathrm{mdeg} \cdot \mathrm{M}^{-\mathrm{n}}\right)\end{array}$ & $\mathrm{R}^{2}$ & $\begin{array}{c}\Delta R_{\max } \\
\text { (mdeg) }\end{array}$ & $\mathrm{n}$ & $\mathrm{K}_{\mathrm{LF}, \mathrm{n}}\left(\mathrm{M}^{-\mathrm{n}}\right)$ & $\mathrm{R}^{2}$ \\
\hline 399 & $2.5 \times 10^{4}$ & 0.994 & 0.44 & $1.6 \times 10^{4}$ & 0.991 & 550 & 0.71 & $2.7 \times 10^{5}$ & 0.998 \\
\hline
\end{tabular}

The analysis of the isotherm models is reported in Table 2. Based on the regression coefficient $\left(R^{2}\right)$ value, the data fit well with all equilibrium isotherm models. The $R_{\max }$ values estimated from the Langmuir-type adsorption isotherm model (357 mdeg) were very close to the maximum experimental value (340 mdeg). In the investigated range of concentrations, it could be assumed that a 1:1 surface complex is formed as described by Reaction (6) between glyphosate and the available surface sites. Moreover, these results indicated that glyphosate binding sites are homogeneously distributed and that there is no interaction between adjacent adsorbed molecules [67].

From Figure 12 showing I effect, it can be concluded that outer-sphere surface complexes are formed in a first stage due to the change in the double-layer thickness and/or by competition between glyphosate and the counter-ions, $\mathrm{Na}^{+}$and $\mathrm{Cl}^{-}$. In such conditions, the electrostatic interaction could control the glyphosate behavior at the CS/ZnO film surface.

\subsection{Selectivity of CS/ZnO Composite Films}

Since the selectivity is a very important property to test the practical application of the chemical sensor with respect to glyphosate, the studies were carried out under optimal conditions for glyphosate, AMPA, glufosinate, and MPPA, at the same concentration $(0.12 \mu \mathrm{M})$ and pH 5.5 (Figure 13). Overall, the CS/ZnO SPR sensor response of glyphosate was 4.3 times higher than the one of AMPA, while the sensor was not sensitive to glufosinate. However, it appeared that the SPR response ratio between MPPA and glyphosate was around 1.15, indicating a better sorption of MPPA to the CS/ZnO than the glyphosate one. 


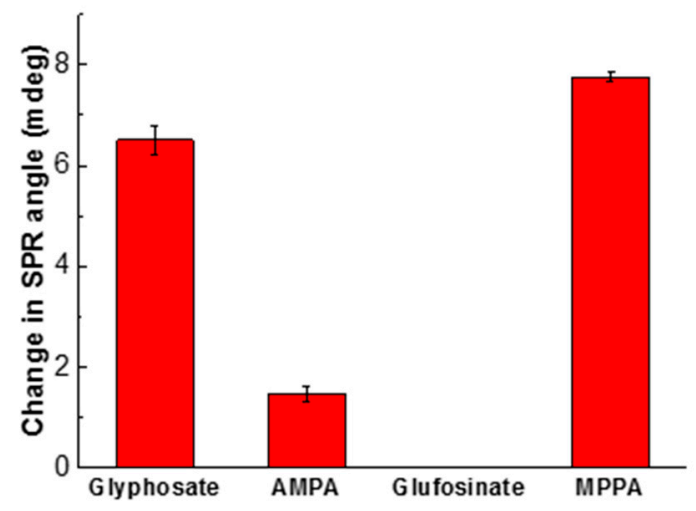

Figure 13. Sorption behavior of glyphosate, AMPA, glufosinate, and MPPA on CS/ZnO SPR sensor at $0.12 \mu \mathrm{M}$ and $\mathrm{pH}$ 5.5. Experimental conditions: injection of each solution separately into the SPR system with a flow rate of $40 \mu \mathrm{L} / \mathrm{min}$ at $20.3^{\circ} \mathrm{C}$.

At $\mathrm{pH} 5.5$, the $\mathrm{CS} / \mathrm{ZnO}$ layer is positively charged, AMPA and glufosinate are -1 negatively charged and MPPA and glyphosate -2 negatively charged. The different charges between AMPA and glufosinate could be due to the location of the $\mathrm{OH}$ groups, closer in the first one compared to the second one. On the other hand, the sorption of MPPA could be more favorable due to the absence of the positive charge in MPPA compared to glyphosate. These results are thus consistent with electrostatic effect and support the fact that sorption is reversible in our experimental conditions, which is critical for sensor development.

\section{Conclusions}

The SPR sensor based on CS and its nanocomposites for the real-time detection of glyphosate in the aquatic system was developed. In this study, different nanomaterials such as $\mathrm{ZnO}$ and GO were incorporated into CS to enhance the sensitivity and selectivity of the SPR sensor. The CS/ZnOSPR sensor exhibited a better sensitivity than CS and CS/GO SPR sensors. Different parameters (cross-linking condition and $\mathrm{pH}$ of sorption) were investigated and optimized for the SPR sensor based on CS/ZnO composite thin film. From the above results, the optical sensor for the detection of glyphosate using SPR and based on CS/ZnO was synthesized and characterized by different techniques such as AFM, FTIR, and contact angle technique. Under the optimal experimental conditions (cross-linking condition and $\mathrm{pH}$ on the sorption of glyphosate), the sensor showed a good linear response vs. glyphosate concentration $(0-0.59 \mu \mathrm{M})$ with estimated LOD and LOQ of $0.008 \mu \mathrm{M}$ and $0.027 \mu \mathrm{M}$, respectively. From isotherm models, the Langmuir-type one can be used to explain the glyphosate sorption behavior. Main mechanisms would be controlled by electrostatic and steric interaction with the possible formation of 1:1 outer-sphere surface complexes between glyphosate and surface sites. In addition, the SPR sensor showed a good selectivity when testing with AMPA and glufosinate, but a lower one in the presence of MPPA. Further work needs to be conducted to improve the selectivity with respect to other molecules such as organic ligands and the impact of some cations before applying this method for monitoring glyphosate in natural waters.

Author Contributions: Conceptualization, P.B., B.D., J.P., G.V.-M., T.-T.N.-T. and N.J.-R.; Funding acquisition, P.B.; Investigation, M.H.D.; Methodology, M.H.D. and B.D.; Project administration, P.B.; Resources, M.H.D., B.D., J.P. and G.V.-M.; Supervision, P.B. and B.D.; Validation, M.H.D., B.D., J.P., G.V.-M. and T.-T.N.-T.; Writing-original draft, M.H.D.; Writing-review and editing, P.B. All authors have read and agreed to the published version of the manuscript.

Funding: This work was partly supported by the MIACTIS project: “Microsystèmes intégrés pour l'analyse des composés en traces in situ" (Integrated microsystems for the analyses of in-situ trace compounds) funded by the RTRA-STAE: thematic network of the foundation for scientific cooperation "Sciences et Technologies pour l'Aéronautique et l'Espace" (Sciences and Technologies for Aeronautic and Space) in Toulouse, France. This work was also supported by the EQUIPEX CRITEX programme (grant no. ANR-11-EQPX-0011, PIs J. Gaillardet, and L. Longuevergne). 
Acknowledgments: Minh Huy Do was granted by the Ministry of Education and Training (MOET) and the University of Science and Technology of Hanoi (USTH), Vietnam Academy of Science and Technology (VAST), Vietnam. The authors thank Marine Tasse (LCC) for AFM analysis. Finally, the authors thank reviewers for their constructive remarks to improve the quality of this paper.

Conflicts of Interest: The authors declare no conflict of interest

\section{References}

1. Kolpin, D.W.; Thurman, E.M.; Lee, E.A.; Meyer, M.T.; Furlong, E.T.; Glassmeyer, S.T. Urban contributions of glyphosate and its degradate AMPA to streams in the United States. Sci. Total Environ. 2006, 354, $191-197$. [CrossRef] [PubMed]

2. Benbrook, C.M. Trends in glyphosate herbicide use in the United States and globally. Environ. Sci. Eur. 2016, 28, 3. [CrossRef] [PubMed]

3. Naydenova, E.D.; Todorov, P.T.; Troev, K.D. Recent synthesis of aminophosphonic acids as potential biological importance. Amino Acids 2010, 38, 23-30. [CrossRef] [PubMed]

4. Martins-Júnior, H.A.; Lebre, D.T.; Wang, A.Y.; Pires, M.A.F.; Bustillos, O.V. An alternative and fast method for determination of glyphosate and aminomethylphosphonic acid (AMPA) residues in soybean using liquid chromatography coupled with tandem mass spectrometry. Rapid Commun. Mass Spectrom. 2009, 23, 1029-1034. [CrossRef] [PubMed]

5. Wong, P.K. Effects of 2,4-D, glyphosate and paraquat on growth, photosynthesis and chlorophyll-a synthesis of Scenedesmus quadricauda Berb 614. Chemosphere 2000, 41, 177-182. [CrossRef]

6. Grunewald, K.; Schmidt, W.; Unger, C.; Hanschmann, G. Behavior of glyphosate and aminomethylphosphonic acid (AMPA) in soils and water of reservoir Radeburg II catchment (Saxony/Germany). J. Plant Nutr. Soil Sci. 2001, 164, 65-70. [CrossRef]

7. Shea, P.J.; Tupy, D.R. Reversal of Cation-Induced Reduction in Glyphosate Activity by EDTA. Weed Sci. 1984, 32, 802-806. [CrossRef]

8. Iummato, M.M.; Fassiano, A.; Graziano, M.; dos Santos Afonso, M.; de Molina, M.D.C.R.; Juárez, Á.B. Effect of glyphosate on the growth, morphology, ultrastructure and metabolism of Scenedesmus vacuolatus. Ecotoxicol. Environ. Saf. 2019, 172, 471-479. [CrossRef]

9. Stuart, M.; Lapworth, D.; Crane, E.; Hart, A. Review of risk from potential emerging contaminants in UK groundwater. Sci. Total Environ. 2012, 416, 1-21. [CrossRef]

10. Dżygiel, P.; Wieczorek, P. Extraction of glyphosate by a supported liquid membrane technique. J. Chromatogr. A 2000, 889, 93-98. [CrossRef]

11. Mallat, E.; Barceló, D. Analysis and degradation study of glyphosate and of aminomethylphosphonic acid in natural waters by means of polymeric and ion-exchange solid-phase extraction columns followed by ion chromatography-post-column derivatization with fluorescence detection. J. Chromatogr. A 1998, 823, 129-136. [CrossRef]

12. Xu, J.; Smith, S.; Smith, G.; Wang, W.; Li, Y. Glyphosate contamination in grains and foods: An overview. Food Control 2019, 106, 106710. [CrossRef]

13. Landrigan, P.J.; Belpoggi, F. The need for independent research on the health effects of glyphosate-based herbicides. Environ. Health 2018, 17, 51. [CrossRef]

14. Xu, Y.; Li, A.J.; Li, K.; Qin, J.; Li, H. Effects of glyphosate-based herbicides on survival, development and growth of invasive snail (Pomacea canaliculata). Aquat. Toxicol. 2017, 193, 136-143. [CrossRef]

15. González-Martínez, M.Á.; Brun, E.M.; Puchades, R.; Maquieira, Á.; Ramsey, K.; Rubio, F. Glyphosate Immunosensor. Application for Water and Soil Analysis. Anal. Chem. 2005, 77, 4219-4227. [CrossRef] [PubMed]

16. Powles, S.B.; Preston, C.; Bryan, I.B.; Jutsum, A.R. Herbicide Resistance: Impact and Management. In Advances in Agronomy; Sparks, D.L., Ed.; Academic Press: San Diego, CA, USA, 1997; Volume 58, pp. 57-93.

17. Grandcoin, A.; Piel, S.; Baurès, E. AminoMethylPhosphonic Acid (AMPA) in natural waters: Its sources, behavior and environmental fate. Water Res. 2017, 117, 187-197. [CrossRef] [PubMed]

18. Lund-HØie, K.; Friestad, H.O. Photodegradation of the herbicide glyphosate in water. Bull. Environ. Contam. Toxicol. 1986, 36, 723-729. [CrossRef] [PubMed] 
19. Hove-Jensen, B.; Zechel, D.L.; Jochimsen, B. Utilization of glyphosate as phosphate source: Biochemistry and genetics of bacterial carbon-phosphorus lyase. Microbiol. Mol. Biol. Rev. 2014, 78, 176-197. [CrossRef]

20. Silva, V.; Mol, H.G.J.; Zomer, P.; Tienstra, M.; Ritsema, C.J.; Geissen, V. Pesticide residues in European agricultural soils - A hidden reality unfolded. Sci. Total Environ. 2019, 653, 1532-1545. [CrossRef]

21. Borggaard, O.K.; Gimsing, A.L. Fate of glyphosate in soil and the possibility of leaching to ground and surface waters: A review. Pest Manag. Sci. 2008, 64, 441-456. [CrossRef]

22. Saunders, E.L.; Pezeshki, R. Glyphosate in Runoff Waters and in the Root-Zone: A Review. Toxics 2015, 3 , 462-480. [CrossRef] [PubMed]

23. Rendon-von Osten, J.; Dzul-Caamal, R. Glyphosate Residues in Groundwater, Drinking Water and Urine of Subsistence Farmers from Intensive Agriculture Localities: A Survey in Hopelchén, Campeche, Mexico. Int. J. Environ. Res. Public Health 2017, 14, 595. [CrossRef] [PubMed]

24. Gillezeau, C.; van Gerwen, M.; Shaffer, R.M.; Rana, I.; Zhang, L.; Sheppard, L.; Taioli, E. The evidence of human exposure to glyphosate: A review. Environ. Health 2019, 18, 2. [CrossRef]

25. Perry, M.J.; Mandrioli, D.; Belpoggi, F.; Manservisi, F.; Panzacchi, S.; Irwin, C. Historical evidence of glyphosate exposure from a US agricultural cohort. Environ. Health 2019, 18, 42. [CrossRef]

26. Van Bruggen, A.H.C.; He, M.M.; Shin, K.; Mai, V.; Jeong, K.C.; Finckh, M.R.; Morris, J.G. Environmental and health effects of the herbicide glyphosate. Sci. Total Environ. 2018, 616-617, 255-268. [CrossRef]

27. Thongprakaisang, S.; Thiantanawat, A.; Rangkadilok, N.; Suriyo, T.; Satayavivad, J. Glyphosate induces human breast cancer cells growth via estrogen receptors. Food Chem. Toxicol. 2013, 59, 129-136. [CrossRef]

28. Williams, G.M.; Aardema, M.; Acquavella, J.; Berry, S.C.; Brusick, D.; Burns, M.M.; de Camargo, J.L.V.; Garabrant, D.; Greim, H.A.; Kier, L.D.; et al. A review of the carcinogenic potential of glyphosate by four independent expert panels and comparison to the IARC assessment. Crit. Rev. Toxicol. 2016, 46, 3-20. [CrossRef]

29. Tarazona, J.V.; Court-Marques, D.; Tiramani, M.; Reich,H.; Pfeil, R.; Istace, F.; Crivellente, F. Glyphosate toxicity and carcinogenicity: A review of the scientific basis of the European Union assessment and its differences with IARC. Arch. Toxicol. 2017, 91, 2723-2743. [CrossRef] [PubMed]

30. Dolan, T.; Howsam, P.; Parsons, D.J.; Whelan, M.J. Is the EU drinking water directive standard for pesticides in drinking water consistent with the precautionary principle? Environ. Sci. Technol. 2013, 47, 4999-5006. [CrossRef] [PubMed]

31. Kataoka, H.; Ryu, S.; Sakiyama, N.; Makita, M. Simple and rapid determination of the herbicides glyphosate and glufosinate in river water, soil and carrot samples by gas chromatography with flame photometric detection. J. Chromatogr. A 1996, 726, 253-258. [CrossRef]

32. Royer, A.; Beguin, S.; Tabet, J.C.; Hulot, S.; Reding, M.A.; Communal, P.Y. Determination of Glyphosate and Aminomethylphosphonic Acid Residues in Water by Gas Chromatography with Tandem Mass Spectrometry after Exchange Ion Resin Purification and Derivatization. Application on Vegetable Matrixes. Anal. Chem. 2000, 72, 3826-3832. [CrossRef] [PubMed]

33. Valle, A.L.; Mello, F.C.C.; Alves-Balvedi, R.P.; Rodrigues, L.P.; Goulart, L.R. Glyphosate detection: Methods, needs and challenges. Environ. Chem. Lett. 2019, 17, 291-317. [CrossRef]

34. Stalikas, C.D.; Pilidis, G.A.; Karayannis, M.I. An integrated gas chromatographic method towards the simultaneous determination of phosphoric and amino acid group containing pesticides. Chromatographia 2000, 51, 741-746. [CrossRef]

35. Jayasumana, C.; Gunatilake, S.; Senanayake, P. Glyphosate, Hard Water and Nephrotoxic Metals: Are They the Culprits Behind the Epidemic of Chronic Kidney Disease of Unknown Etiology in Sri Lanka? Int. J. Environ. Res. Public Health 2014, 11, 2125-2147. [CrossRef] [PubMed]

36. Goodwin, L.; Startin, J.R.; Keely, B.J.; Goodall, D.M. Analysis of glyphosate and glufosinate by capillary electrophoresis-mass spectrometry utilising a sheathless microelectrospray interface. J. Chromatogr. A 2003, 1004, 107-119. [CrossRef]

37. Noori, J.S.; Dimaki, M.; Mortensen, J.; Svendsen, W.E. Detection of Glyphosate in Drinking Water: A Fast and Direct Detection Method without Sample Pretreatment. Sensors 2018, 18, 2961. [CrossRef] [PubMed]

38. Mirmohseni, A.; Farhadi, K.; Jahangiri, S. Application of polydimethylsiloxane/acrylic resins coated quartz crystal nano balance sensor for detection of glyphosate pesticide. Int. J. Environ. Anal. Chem. 2019, 2, 1-13. [CrossRef] 
39. Rettke, D.; Döring, J.; Martin, S.; Venus, T.; Estrela-Lopis, I.; Schmidt, S.; Ostermann, K.; Pompe, T. Picomolar glyphosate sensitivity of an optical particle-based sensor utilizing biomimetic interaction principles. Biosens. Bioelectron. 2020, 165, 11226. [CrossRef]

40. Skeff, W.; Recknagel, C.; Düwel, Y.; Schulz-Bull, D.E. Adsorption behaviors of glyphosate, glufosinate, aminomethylphosphonic acid, and 2-aminoethylphosphonic acid on three typical Baltic Sea sediments. Mar. Chem. 2018, 198, 1-9. [CrossRef]

41. Saleviter, S.; Fen, Y.W.; Omar, N.A.S.; Zainudin, A.A.; Daniyal, W.M.E.M.M. Optical and structural characterization of immobilized 4-(2-pyridylazo)resorcinol in chitosan-graphene oxide composite thin film and its potential for Co2+ sensing using surface plasmon resonance technique. Results Phys. 2018, 11, 118-122. [CrossRef]

42. Ramdzan, N.S.M.; Fen, Y.W.; Omar, N.A.S.; Anas, N.A.A.; Daniyal, W.M.E.M.M.; Saleviter, S.; Zainudin, A.A. Optical and surface plasmon resonance sensing properties for chitosan/carboxyl-functionalized graphene quantum dots thin film. Optik 2019, 178, 802-812. [CrossRef]

43. Hinman, S.S.; McKeating, K.S.; Cheng, Q. Surface Plasmon Resonance: Material and Interface Design for Universal Accessibility. Anal. Chem. 2018, 90, 19-39. [CrossRef] [PubMed]

44. Jing, L.; Zhang, Q.; Wang, Y.; Liu, X.; Wei, T. Surface plasmon resonance sensor for theophylline using a water-compatible molecularly imprinted film. Anal. Methods 2016, 8, 2349-2356. [CrossRef]

45. Lokman, N.F.; Bakar, A.A.A.; Suja, F.; Abdullah, H.; Rahman, W.B.W.A.; Huang, N.-M.; Yaacob, M.H. Highly sensitive SPR response of $\mathrm{Au}$ /chitosan/graphene oxide nanostructured thin films toward $\mathrm{Pb}$ (II) ions. Sens. Actuators B Chem. 2014, 195, 459-466. [CrossRef]

46. Fen, Y.W.; Yunus, W.M.M.; Talib, Z.A.; Yusof, N.A. Development of surface plasmon resonance sensor for determining zinc ion using novel active nanolayers as probe. Spectrochim. Acta Part A Mol. Biomol. Spectrosc. 2015, 134, 48-52. [CrossRef] [PubMed]

47. Chen, B.; Liu, C.; Ge, L.; Hayashi, K. Localized surface plasmon resonance gas sensor of Au nano-islands coated with molecularly imprinted polymer: Influence of polymer thickness on sensitivity and selectivity. Sens. Actuators B Chem. 2016, 231, 787-792. [CrossRef]

48. Dhara, P.; Singh, V.K.; Olivero, M.; Perrone, G. Reflectance-based low-cost disposable optical fiber surface plasmon resonance probe with enhanced biochemical sensitivity. Opt. Eng. 2016, 55, 046114. [CrossRef]

49. Xue, T.; Qi, K.; Hu, C. Novel SPR sensing platform based on superstructure MoS2 nanosheets for ultrasensitive detection of mercury ion. Sens. Actuators B Chem. 2019, 284, 589-594. [CrossRef]

50. Aguirre, M.N.; Pérez, M.L.; Colín, A.J.; Buenrostro-Gonzalez, E. Development of a Surface Plasmon Resonance n-dodecane Vapor Sensor. Sensors 2007, 7, 1954-1961. [CrossRef]

51. Zargar, V.; Asghari, M.; Dashti, A. A Review on Chitin and Chitosan Polymers: Structure, Chemistry, Solubility, Derivatives, and Applications. Chembioeng Rev. 2015, 2, 204-226. [CrossRef]

52. Ibrahim, K.A.; El-Eswed, B.I.; Abu-Sbeih, K.A.; Arafat, T.A.; Al Omari, M.M.H.; Darras, F.H.; Badwan, A.A. Preparation of Chito-Oligomers by Hydrolysis of Chitosan in the Presence of Zeolite as Adsorbent. Mar. Drugs 2016, 14, 43.

53. Desbrières, J.; Guibal, E. Chitosan for wastewater treatment. Polym. Int. 2018, 67, 7-14.

54. Birlik, E.; Büyüktiryaki, S.; Ersöz, A.; Denizli, A.; Say, R. Selective Separation of Thorium Using Ion Imprinted Chitosan-Phthalate Particles via Solid Phase Extraction. Sep. Sci. Technol. 2006, 41, 3109-3121.

55. Monteiro, O.A.C.; Airoldi, C. Some studies of crosslinking chitosan-glutaraldehyde interaction in a homogeneous system. Int. J. Biol. Macromol. 1999, 26, 119-128. [PubMed]

56. Gonçalves, V.; Fávere, V.; Rozangela, P.C. Effect of crosslinking agents on chitosan microspheres in controlled release of diclofenac sodium. Polimeros 2005, 15, 6-12.

57. Luk, C.; Yip, J.; Yuen, C.M.; Kan, C.; Lam, K. A Comprehensive Study on Adsorption Behaviour of Direct, Reactive and Acid Dyes on Crosslinked and Non-crosslinked Chitosan Beads. J. Fiber Bioeng. Inform. 2014, 7, $35-52$.

58. Mcllwee, H.A.; Schauer, C.L.; Praig, V.G.; Boukherroub, R.; Szunerits, S. Thin chitosan films as a platform for SPR sensing of ferric ions. Analyst 2008, 133, 673-677.

59. Zainudin, A.A.; Fen, Y.W.; Yusof, N.A.; Al-Rekabi, S.H.; Mahdi, M.A.; Omar, N.A.S. Incorporation of surface plasmon resonance with novel valinomycin doped chitosan-graphene oxide thin film for sensing potassium ion. Spectrochim. Acta Part A Mol. Biomol. Spectrosc. 2018, 191, 111-115. 
60. Tabassum, R.; Gupta, B.D. Fiber optic manganese ions sensor using SPR and nanocomposite of ZnO-polypyrrole. Sens. Actuators B Chem. 2015, 220, 903-909.

61. Baccarin, M.; Santos, F.A.; Vicentini, F.C.; Zucolotto, V.; Janegitz, B.C.; Fatibello-Filho, O. Electrochemical sensor based on reduced graphene oxide/carbon black/chitosan composite for the simultaneous determination of dopamine and paracetamol concentrations in urine samples. J. Electroanal. Chem. 2017, 799, 436-443.

62. Magesh, G.; Bhoopathi, G.; Nithya, N.; Arun, A.P.; Ranjith Kumar, E. Tuning effect of polysaccharide Chitosan on structural, morphological, optical and photoluminescence properties of ZnO nanoparticles. Superlattices Microstruct. 2018, 117, 36-45. [CrossRef]

63. Sari, E.; Üzek, R.; Duman, M.; Denizli, A. Fabrication of surface plasmon resonance nanosensor for the selective determination of erythromycin via molecular imprinted nanoparticles. Talanta 2016, 150, 607-614. [CrossRef] [PubMed]

64. Sigg, L.; Behra, P.; Stumm, W. Chimie des Milieux Aquatiques; Dunod: Paris, France, 2014.

65. Charrière, D.; Cortázar, M.D.A.H.; Behra, P. Effect of the presence of pyrite traces on silver behavior in natural porous media. J. Colloid Interface Sci. 2015, 446, 379-385. [CrossRef] [PubMed]

66. Yılmaz, E.; Özgür, E.; Bereli, N.; Türkmen, D.; Denizli, A. Plastic antibody based surface plasmon resonance nanosensors for selective atrazine detection. Mater. Sci. Eng. C 2017, 73, 603-610. [CrossRef]

67. Yola, M.L.; Eren, T.; Atar, N. Molecular imprinted nanosensor based on surface plasmon resonance: Application to the sensitive determination of amoxicillin. Sens. Actuators B Chem. 2014, 195, 28-35. [CrossRef]

68. Dabrowski, A.; Jaroniec, M. Effects of surface heterogeneity in adsorption from binary liquid mixtures: III. Analysis of experimental data by using Langmuir-Freundlich type equations. J. Colloid Interface Sci. 1980, $73,475-482$.

69. Burghoff, H.G.; Pusch, W. A model of physical adsorption of gases. J. Appl. Polym. Sci. 1979, 24, 1479-1495. [CrossRef]

70. Gustavo González, A.; Ángeles Herrador, M. A practical guide to analytical method validation, including measurement uncertainty and accuracy profiles. TrAC Trends Anal. Chem. 2007, 26, 227-238. [CrossRef]

71. Yusof, N.A.A.; Zain, N.M.; Pauzi, N. Synthesis of ZnO nanoparticles with chitosan as stabilizing agent and their antibacterial properties against Gram-positive and Gram-negative bacteria. Int. J. Biol. Macromol. 2019, 124, 1132-1136. [CrossRef]

72. Li, L.-H.; Deng, J.-C.; Deng, H.-R.; Liu, Z.-L.; Xin, L. Synthesis and characterization of chitosan/ZnO nanoparticle composite membranes. Carbohydr. Res. 2010, 345, 994-998. [CrossRef]

73. Pires, N.R.; Cunha, P.L.R.; Maciel, J.S.; Angelim, A.L.; Melo, V.M.M.; de Paula, R.C.M.; Feitosa, J.P.A. Sulfated chitosan as tear substitute with no antimicrobial activity. Carbohydr. Polym. 2013, 91, 92-99. [CrossRef] [PubMed]

74. Zając, A.; Hanuza, J.; Wandas, M.; Dymińska, L. Determination of N-acetylation degree in chitosan using Raman spectroscopy. Spectrochim. Acta Part A Mol. Biomol. Spectrosc. 2015, 134, 114-120. [CrossRef] [PubMed]

75. Chen, C.Y.; Yang, C.Y.; Chen, A.H. Biosorption of $\mathrm{Cu}(\mathrm{II}), \mathrm{Zn}(\mathrm{II}), \mathrm{Ni}(\mathrm{II})$ and $\mathrm{Pb}(\mathrm{II})$ ions by cross-linked metal-imprinted chitosans with epichlorohydrin. J. Environ. Manag. 2011, 92, 796-802. [CrossRef] [PubMed]

76. Gök, M.K.; Demir, K.; Cevher, E.; Özgümüş, S.; Pabuccuoğlu, S. Effect of the linear aliphatic amine functionalization on in vitro transfection efficiency of chitosan nanoparticles. Carbohydr. Polym. 2019, 207, 580-587. [CrossRef]

77. Tsui, M.T.K.; Wang, W.-X.; Chu, L.M. Influence of glyphosate and its formulation (Roundup®) on the toxicity and bioavailability of metals to Ceriodaphnia dubia. Environ. Pollut. 2005, 138, 59-68. [CrossRef]

78. Anandhavelu, S.; Thambidurai, S. Single step synthesis of chitin/chitosan-based graphene oxide-ZnO hybrid composites for better electrical conductivity and optical properties. Electrochim. Acta 2013, 90, 194-202. [CrossRef]

79. Torres, M.A.; Beppu, M.M.; Santana, C.C. Characterization of chemically modified chitosan microspheres as adsorbents using standard Proteins. Braz. J. Chem. Eng. 2007, 24, 325-336.

80. Webster, A.; Halling, M.D.; Grant, D.M. Metal complexation of chitosan and its glutaraldehyde cross-linked derivative. Carbohydr. Res. 2007, 342, 1189-1201. [CrossRef] 
81. Yong, S.K.; Shrivastava, M.; Srivastava, P.; Kunhikrishnan, A.; Bolan, N. Environmental Applications of Chitosan and Its Derivatives. In Reviews of Environmental Contamination and Toxicology; Whitacre, D.M., Ed.; Springer International Publishing: Cham, Switzerland, 2015; Volume 233, pp. 1-43.

82. Stumm, W. Chemistry of the Solid-Water Interface: Processes at the Mineral-Water and Particle-Water Interface in Natural Systems; John Wiley \& Sons: New York, NY, USA, 1992.

83. Stumm, W.; Morgan, J.J. Aquatic Chemistry: Chemical Equilibria and Rates in Natural Waters, 3rd ed.; John Wiley \& Sons: New York, NY, USA, 1996.

84. Mash, H.E.; Chin, Y.P.; Sigg, L.; Hari, R.; Xue, H.H. Complexation of copper by zwitterionic aminosulfonic (good) buffers. Anal. Chem. 2003, 75, 671-677. [CrossRef]

85. Wernert, V. Rôle de la Matière Organique Dans le Transport et la Spéciation du Mercure. Ph.D. Thesis, University of Strasbourg, Strasbourg, France, 2004. (In French).

86. Kamaruddin, N.H.; Bakar, A.A.A.; Mobarak, N.N.; Zan, M.S.D.; Arsad, N. Binding affinity of a highly sensitive au/ag/au/chitosan-graphene oxide sensor based on direct detection of $\mathrm{Pb}^{2+}$ and $\mathrm{Hg}^{2+}$ ions. Sensors 2017, 17, 2277. [CrossRef] [PubMed]

87. Kamaruddin, N.H.; Bakar, A.A.A.; Yaacob, M.H.; Mahdi, M.A.; Zan, M.S.D.; Shaari, S. Enhancement of chitosan-graphene oxide SPR sensor with a multi-metallic layers of Au-Ag-Au nanostructure for lead(II) ion detection. Appl. Surf. Sci. 2016, 361, 177-184. [CrossRef]

88. Fen, Y.W.; Yunus, W.M.M.; Yusof, N.A. Surface plasmon resonance optical sensor for detection of $\mathrm{Pb}^{2+}$ based on immobilized p-tert-butylcalix[4]arene-tetrakis in chitosan thin film as an active layer. Sens. Actuators $B$ Chem. 2012, 171-172, 287-293. [CrossRef]

89. Yu, Q.; Deng, S.; Yu, G. Selective removal of perfluorooctane sulfonate from aqueous solution using chitosan-based molecularly imprinted polymer adsorbents. Water Res. 2008, 42, 3089-3097. [CrossRef] [PubMed]

90. Özkütük, E.B.; Diltemiz, S.E.; Özalp, E.; Gedikbey, T.; Ersöz, A. Paraoxon imprinted biopolymer based QCM sensor. Mater. Chem. Phys. 2013, 139, 107-112. [CrossRef]

91. Góes, R.E.D.; Possetti, G.R.C.; Muller, M.; Fabris, J.L. Optical Detection of Glyphosate in Water. In Proceedings of the 25th Optical Fiber Sensors Conference (OFS), Jeju, Korea, 24-28 April 2017; pp. 1-4.

92. De Góes, R.E.; Muller, M.; Fabris, J.L. Spectroscopic Detection of Glyphosate in Water Assisted by Laser-Ablated Silver Nanoparticles. Sensors 2017, 17, 954. [CrossRef] [PubMed]

93. De Almeida, L.K.S.; Chigome, S.; Torto, N.; Frost, C.L.; Pletschke, B.I. A novel colorimetric sensor strip for the detection of glyphosate in water. Sens. Actuators B Chem. 2015, 206, 357-363. [CrossRef]

94. Wang, D.; Lin, B.; Cao, Y.; Guo, M.; Yu, Y. A Highly Selective and Sensitive Fluorescence Detection Method of Glyphosate Based on an Immune Reaction Strategy of Carbon Dot Labeled Antibody and Antigen Magnetic Beads. J. Agric. Food Chem. 2016, 64, 6042-6050. [CrossRef]

95. Rawat, K.A.; Majithiya, R.P.; Rohit, J.V.; Basu, H.; Singhal, R.K.; Kailasa, S.K. Mg2+ ion as a tuner for colorimetric sensing of glyphosate with improved sensitivity via the aggregation of 2-mercapto-5-nitrobenzimidazole capped silver nanoparticles. RSC Adv. 2016, 6, 47741-47752. [CrossRef]

96. Döring, J.; Rettke, D.; Rödel, G.; Pompe, T.; Ostermann, K. Surface Functionalization by Hydrophobin-EPSPS Fusion Protein Allows for the Fast and Simple Detection of Glyphosate. Biosensors 2019, 29, 104. [CrossRef] [PubMed]

Publisher's Note: MDPI stays neutral with regard to jurisdictional claims in published maps and institutional affiliations.

(C) 2020 by the authors. Licensee MDPI, Basel, Switzerland. This article is an open access article distributed under the terms and conditions of the Creative Commons Attribution (CC BY) license (http://creativecommons.org/licenses/by/4.0/). 